\title{
Morphological and Molecular Studies on Termitomyces Species of Menge District, Asossa Zone, Northwest Ethiopia
}

\author{
Rediet Sitotaw ${ }^{1,2^{*}}$, Anteneh Mulat ${ }^{1}$ and Dawit Abate $^{2}$ \\ ${ }^{1}$ Department of Biology, College of Natural and Computational Sciences, Wollega University, P. O. Box 395, \\ Nekemte, Ethiopia \\ ${ }^{2}$ Microbial, Cellular and Molecular Biology Department, Addis Ababa University, P.O. Box 1176, \\ Addis Ababa, Ethiopia
}

\begin{tabular}{|c|c|}
\hline Abstract & \\
\hline $\begin{array}{l}\text { Despite the extensive study on plant and animal biodiversity in Ethiopia, our knowledge of } \\
\text { microbial diversity in general and macrofungal diversity in particular is very limited. Thus, as } \\
\text { part of the ongoing study on macrofungal diversity of the country, this is the first report on } \\
\text { morphological and molecular taxonomy of the genus Termitomyces in the country. In this } \\
\text { particular report, we identified seven Termitomyces species collected from Menge Districts, } \\
\text { Asossa Zone, Benshangul Gumuz region. Identification was based on morphological } \\
\text { characteristics and partial LSU rDNA sequences. The results of morphological identification } \\
\text { of each of our collection were supported with molecular investigation. Phylogenetic analysis } \\
\text { of partial LSU rDNA sequences of } 7 \text { Ethiopian Termitomyces species using Distance, } \\
\text { Parsimony measurements and Maximum Likelihood presented similar inferred trees that } \\
\text { only had minor differences. Based on these phylogenetic analyses of the partial LSU rDNA } \\
\text { sequences, } 7 \text { species of Termitomyces were identified as } T \text {. aurantiacus, } T \text {. clypeatus, } T \text {. } \\
\text { eurrhizus, } T \text {. letestui, T. microcarpus, T. robustus and T. schimperi. The inferred ML } \\
\text { cladogram revealed both Asian and African Termitomyces samples in our analysis } \\
\text { demonstrated a well-supported monophyletic group with bootstrap value of } 99 \% \text {. Moreover, } \\
\text { the monophyletic tree from pure Ethiopian Termitomyces collection and a combination of } \\
\text { African and Asian Termitomyces samples suggested their common origin. However } \\
\text { incorporating more samples, more DNA markers and extensive analyses may reveal the true } \\
\text { link among the sequences from different regions of the world. All the species reported are } \\
\text { used for culinary purposes by the native community and few of them (T. microcarpus and T. } \\
\text { clypeatus) are used for treatment of indigestion and malnutrition. } \\
\text { Copyright@2015 STAR Journal, Wollega University. All Rights Reserved. }\end{array}$ & $\begin{array}{l}\text { Macrofungi } \\
\text { Termitomyces } \\
\text { Morphology } \\
\text { Phylogeny } \\
\text { Taxonomy } \\
{ }^{*} \text { Corresponding Author: } \\
\text { Rediet Sitotaw } \\
\text { E-mail: } \\
\text { redietsitotaw7@gmail.com }\end{array}$ \\
\hline
\end{tabular}

\section{INTRODUCTION}

Termitomyces R. Heim 1942 comprises a group of gilled mushrooms termed termitophilic which live in association with a particular family of termites Macrotermitinae (Isoptera) commonly found in Africa and Asia with a warm and humid climate (Kirk et al., 2008). Once this group of macrofungi were reported as an independent genus by Heim (1942) with 10 species, a number of species of this genus have been described predominantly from tropical areas (Heim, 1952, 1977) mainly Africa (Heim 1942; Pegler 1977; Otieno 1964; Van der Westhuizen \& Eicker 1990; Mossebo et al., 2002; Pegler and Rayner, 1969; Moriss, 1986), South America (Otieno 1964, Alasoadura 1966, Gómez, 1995) and South East Asia (Zhang et al., 1986; Wei et al., 2003, 2004; Tang et al., 2006). Altogether, 68 taxa have been published in this genus, with 81 names containing combinations and autonyms (Kirk et al., 2008), however the taxonomic statuses of some of them are still doubtful.
Termitomyces species are typically characterized by the termite association, pinkish spore print, smooth basidiospores, conspicuous perforatorium on pileus and underground pseudorhiza connected to the comb in the termite nest (Heim 1977, Frøslev et al., 2003). Recent molecular phylogenetic analysis on species in this genus showed that, they form a monophyletic clade in Agaricales (Moncalvo et al., 2000, Aanen et al., 2002), although this genus genetically show geographic variation between Asia and Africa species (Frøslev et al., 2003).

Although Ethiopia is known to have highly diverse flora and fauna (Friis and Sebsebe 2001) the diversity, ecology, and distribution of macrofungi in general and genus Termitomyces in particular has been poorly explored. However the genus comprises species which are the choice edible mushrooms, it has not been a focus of taxonomic investigation among mycologists in the country. The reports on this genus so far were mainly 
Rediet Sitotaw et al.,

based on the local use of these fungi for food and medicine among most communities in rural areas of South and South-West part of the country (Teferi et al., 2013). Any of these reports did not provide a detailed morphological description or any molecular data of the species in the genus, thus the taxonomic status of these species is not clear. However, there has been a recent molecular taxonomic work by Sitotaw et al., (2015) on the genus Agaricus.

From the ongoing study on the diversity of macrofungi of the country, this is the first report on taxonomic study based on morphological and molecular characteristics of Termitomyces collections from Menge districts, Northwest Ethiopia. This paper provides a description of seven Termitomyces collections based on morphological diagnosis and molecular data analyzed using LSU rDNA. The results reported here will provide points of reference
Sci. Technol. Arts Res. J., Oct-Dec 2015, 4(4): 49-57

to facilitate taxonomic, ethnomycological, ecological and economic studies on Ethiopian Termitomyces species.

\section{MATERIALS AND METHODS}

\section{Collection Site}

Specimens were collected form Menge District, Asossa Zone, Benishangul Gumuz region, located in the Northwest part of Ethiopia. It is found $720 \mathrm{~km}$ North West of Addis Ababa and $40 \mathrm{~km}$ to the north of Asossa town (the capital of the region). The District is geographically located between $34^{\circ} 30^{\circ}$ to $35^{\circ} 10^{\circ} \mathrm{E}$ and $10^{\circ} 00$ to $10^{\circ} 30$ $\mathrm{N}$. Topography of the region is composed of mainly low land and plains and a few mountainous and gorges, altitude ranges from about $600-1700 \mathrm{~m}$ a.s.l. About 55\% of the total land area of the district is covered by natural vegetation, especially bamboo thickets, broad-leaved deciduous woodlands and acacia woodlands, grazing and cultivated land (BRFSS, 2004).

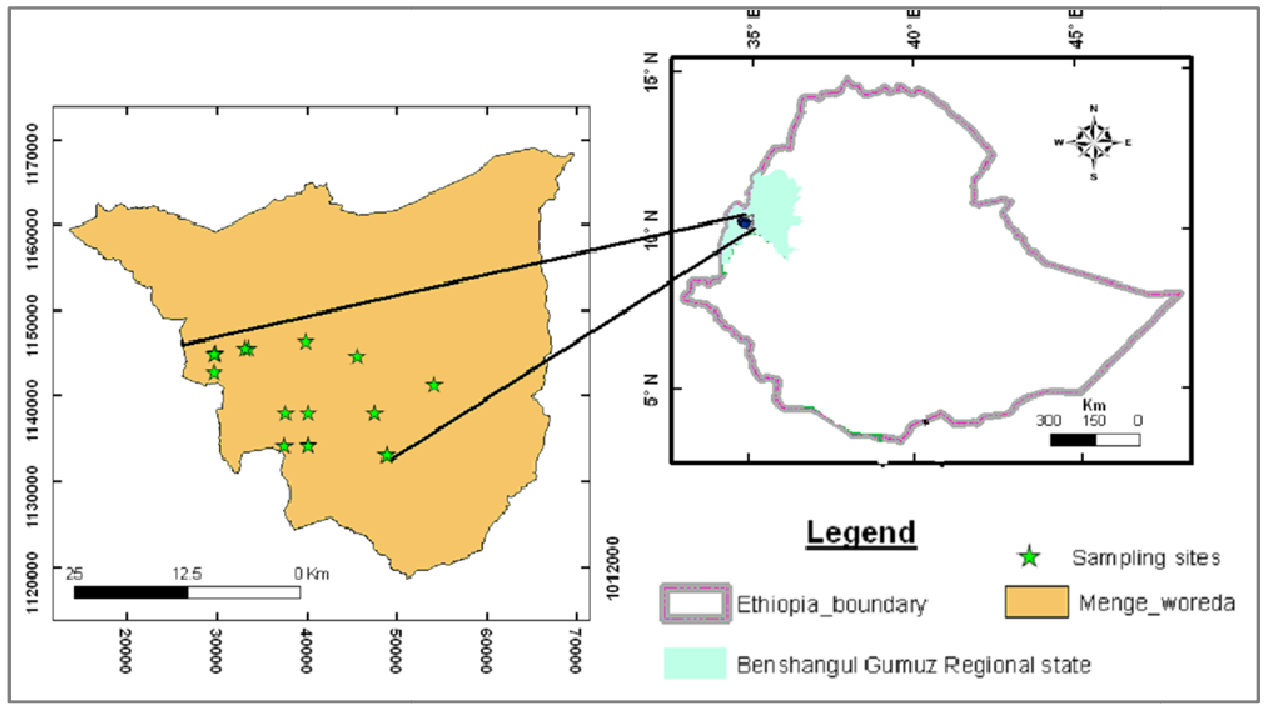

Figure 1: Map of Ethiopia and the study area

Meteorological data obtained from Ethiopian Meteorological Agency (Asossa Branch Office), the surrounding area has mean minimum and maximum temperatures of $12^{\circ} \mathrm{C}$ and $32^{\circ} \mathrm{C}$, respectively. The temperature reaches a daily maximum of $20^{\circ} \mathrm{C}$ to $25^{\circ} \mathrm{C}$ in the rainy season and rises to $35^{\circ} \mathrm{C}$ to $40^{\circ} \mathrm{C}$ in the dry season (February to April). The rainfall in the area is unimodal and obtains high rainfall from May to October. Annual rainfall varies from 800 to $2000 \mathrm{~mm}$. Generally, the rainfall is erratic from year to year (BRFSS, 2004).

\section{Morphological Observation}

Field collections were made during June-September, 2012-2014 in side forest, grazing land, around farm fields and backyards. Basidiomata were photographed (Canon A470) and their morphological and ecological characteristics were noted, labelled and brought to Mycology Laboratory, Addis Ababa University for detail microscopic and macroscopic characterization. Small pieces from the inner tissues of each specimen were collected using sterile forceps and stored at $-20^{\circ} \mathrm{C}$ for DNA extraction.

Microscopical observations were made from specimens mounted in $5 \% \mathrm{KOH}$ and stained with $1 \%$ aqueous Melzer's reagent and Congo red. Sections of pileus, lamellae and context were prepared with a razor blade and then observed under light microscope. At least twenty basidiospores were measured from each specimen. All the collections were dried and deposited in the department of Microbial, Cellular and Molecular Biology, Addis Ababa University, Ethiopia and duplicates are preserved in the Fungarium, Institute of Microbiology, Chinese Academy of Sciences, Beijing, China (HMAS). Morphological identification was assisted with basic literatures including Pegler (1977), Pegler and Piearce (1980) and Singer (1986).

DNA Extraction, PCR Amplification, and Sequencing

Total genomic DNA was extracted using the modified CTAB method described by Yao et al. (1999). The fungal universal primer pair LR0R/LR5 were used to amplify the nuclear larger subunit RNA (LSU) region (White et al., 1990). The PCR reaction mixture was comprised $25 \mu \mathrm{l}$ Taq PCR MasterMix, $0.5 \mu \mathrm{l}$ of $10 \mu \mathrm{M}$ each primer, $1 \mu \mathrm{l}$ diluted DNA template, and RNase-Free water to bring the total volume to $50 \mu \mathrm{l}$. The PCR conditions were set as follows: $94{ }^{\circ} \mathrm{C}$ for $5 \mathrm{~min}$, followed by 35 cycles of $95^{\circ} \mathrm{C}$ for $1 \mathrm{~min}, 53{ }^{\circ} \mathrm{C}$ for $1 \mathrm{~min}, 72^{\circ} \mathrm{C}$ for $1 \mathrm{~min}$ and final extension step of $72{ }^{\circ} \mathrm{C}$ for $10 \mathrm{~min}$ on a GenAmp PCR System 9700 thermocycler (Vers. 3.03). 
Rediet Sitotaw et al.,

PCR products were sequenced from both directions using the same primers on an Applied Biosystems 3730 Analyzertm by the Beijing Genomics Institute (Beijing, China). Sequence ends were manually edited and assembled using DNAStar Lasergene SeqManTM II vers. 6.1. Sequences were then aligned using Clustal W algorithm (Thompson et al., 1994) and manually edited with BioEdit vers. 7.1.9 (Hall 1999).

\section{Phylogenetic Analysis}

Sequences of LSU were obtained from 10 Termitomyces collections in this study and aligned together with 35 closely related LSU rDNA sequences of Termitomyces species and 2 out-group taxa (Lyophyllum semitale and Lyophyllum atratum) which were
Sci. Technol. Arts Res. J., Oct-Dec 2015, 4(4): 49-57

downloaded from GenBank (Table 1). The LSU sequences obtained in this study were submitted to GenBank as KU933604 - 933612 and 933614 Evolutionary analyses were conducted in MEGA6 (Tamura et al., 2013). The evolutionary history was inferred by using the Maximum Likelihood (ML) method based on the Kimura 2-parameter model (Kimura, 1980). The tree with the highest log likelihood $(-1318.5755)$ is shown. Initial tree(s) for the heuristic search were obtained automatically by applying the Maximum Parsimony method. The tree was drawn to scale, with branch lengths measured in the number of substitutions per site. The analysis involved 47 nucleotide sequences. There were a total of 595 positions in the final dataset.

Table 1: LSU sequences of Termitomyces and out-group species used in the phylogenetic analysis

\begin{tabular}{|c|c|c|c|c|}
\hline Species & Voucher/isolate & Origin & GenBank* LSU & References \\
\hline \multirow[t]{5}{*}{ Termitomyces aurantiacus } & $\operatorname{tgf82}$ & Tanzania & AY127804 & Aanen et al. (2003) \\
\hline & $\operatorname{tgf89}$ & Cameroon & AY232690 & Froslev et al. (2003) \\
\hline & $\operatorname{tgf85}$ & Thailand & AY232691 & Froslev et al. (2003) \\
\hline & HMAS273464 & Ethiopia & KU933605 & This study \\
\hline & HMAS273466 & Ethiopia & KU933608 & This study \\
\hline \multirow[t]{4}{*}{ T. clypeatus } & JMleq.MUID & Asia & AF261398 & Moncalvo et al. (2002) \\
\hline & $\operatorname{tgf93}$ & Burundi & AY127803 & Aanen et al. (2002) \\
\hline & PG & Malaysia & HM036342 & Tan et al. (2010) \\
\hline & HMAS273462 & Ethiopia & KU933604 & This Study \\
\hline T. cylindricus & JM/leg.R.S & USA & AF042585 & Moncalvo et al. (2000) \\
\hline T. aff. entolomoides & $\operatorname{tgf10}$ & Malaysia & AY232692 & Froslev et al. (2003) \\
\hline T. entolomoides & $\operatorname{tgf103}$ & Africa & AY232693 & Froslev et al. (2003) \\
\hline \multirow[t]{3}{*}{ T. eurhizus } & $\operatorname{tgf101}$ & Burundi & AY232694 & Froslev et al. (2003) \\
\hline & HMAS273459 & Ethiopia & KU933607 & This study \\
\hline & HMAS273458 & Ethiopia & KU933609 & This study \\
\hline T. globulus & $\operatorname{tg} 111$ & Cameroon & AY232695 & Froslev et al. (2003) \\
\hline \multirow[t]{3}{*}{ T. heimii } & JM/leg.S & Asia & AF042586 & Moncalvo et al. (2000) \\
\hline & $\operatorname{tgf9}$ & Malaysia & AY232696 & Froslev et al. (2003) \\
\hline & TB & Malaysia & HM036345 & Tan et al. (2010) \\
\hline \multirow[t]{4}{*}{ T. letestui } & $\operatorname{tgf} 16$ & Zimbabwe & AY 127800 & Aanen et al. (2002) \\
\hline & $\operatorname{tg} 5$ & Cameroon & AY232699 & Froslev et al. (2003) \\
\hline & $\operatorname{tgf83}$ & Denmark & AY232698 & Froslev et al. (2003) \\
\hline & HMAS273763 & Ethiopia & KU933606 & This study \\
\hline \multirow[t]{3}{*}{ T. mammiformis } & $\operatorname{tg} f 100$ & Burundi & AY232701 & Froslev et al. (2003) \\
\hline & $\operatorname{tgf102}$ & Burundi & AY232700 & Froslev et al. (2003) \\
\hline & $\operatorname{tgf92}$ & Burundi & AY232703 & Froslev et al. (2003) \\
\hline \multirow[t]{3}{*}{ T. medius } & dka138 & Cameroon & AY127796 & Aanen et al. (2003) \\
\hline & $\operatorname{tgf70}$ & Cameroon & AY232704 & Froslev et al. (2003) \\
\hline & $\operatorname{tgf7}$ & Cameroon & AY232705 & Froslev et al. (2003) \\
\hline \multirow[t]{5}{*}{ T. microcarpus } & $\operatorname{tgf}$ & Tanzania & AY127799 & Froslev et al. (2003) \\
\hline & $\operatorname{tgf88}$ & Tanzania & AY232708 & Froslev et al. (2003) \\
\hline & $\operatorname{tgf80}$ & Tanzania & AY232707 & Froslev et al. (2003) \\
\hline & $\operatorname{tgf} 86$ & Zimbabwe & AY232706 & Froslev et al. (2003) \\
\hline & HMAS273461 & Ethiopia & KU933610 & This study \\
\hline \multirow[t]{5}{*}{ T. robustus } & $\operatorname{tgf95}$ & Burundi & AY127797 & Aanen et al. (2003) \\
\hline & $\operatorname{tgf72}$ & Tanzania & AY232710 & Froslev et al. (2003) \\
\hline & $\operatorname{tgf} 81$ & Tanzania & AY232709 & Froslev et al. (2003) \\
\hline & HMAS273465 & Ethiopia & KU933611 & This study \\
\hline & HMAS273456 & Ethiopia & KU933612 & This study \\
\hline \multirow[t]{2}{*}{ T. schimperi } & $\operatorname{tgf} 18$ & Zimbabwe & AY232712 & Froslev et al. (2003) \\
\hline & HMAS273460 & Ethiopia & KU933614 & This study \\
\hline T. singidensis & $\operatorname{tgf74}$ & Tanzania & AY232713 & Froslev et al. (2003) \\
\hline T. striatus & $\operatorname{tgf99}$ & Burundi & AY232714 & Froslev et al. (2003) \\
\hline T. subhyalinus & - & Switzerland & AF223174 & Moncalvo et al. (2002) \\
\hline \multirow[t]{2}{*}{ T. titanicus } & $\operatorname{tgf96}$ & Burundi & AY232715 & Froslev et al. (2003) \\
\hline & $\operatorname{tgf94}$ & Burundi & AY127801 & Aanen et al. (2003) \\
\hline Lyophyllum semitale & $\mathrm{HC} 85 / 13$ & USA & AF042581 & Moncalvo et al. (2000) \\
\hline Lyophyllum atratum & CBS 709.87 & Switzerland & AF223210 & Moncalvo et al. (2002) \\
\hline
\end{tabular}


Rediet Sitotaw et al.,

\section{RESULTS AND DISCUSSION}

Phylogenetic Analyses

Phylogenetic analysis of partial LSU rDNA sequences of 10 Ethiopian Termitomyces collections using Distance, Parsimony measurements (trees not shown) and Maximum Likelihood presented similar inferred trees that only had minor differences. Based on these phylogenetic analyses of the partial LSU rDNA sequences, 7 species of Termitomyces were identified as $T$. aurantiacus, $T$. clypeatus, T. eurrhizus, T. letestui, T. microcarpus, $T$.
Sci. Technol. Arts Res. J., Oct-Dec 2015, 4(4): 49-57

robustus and $T$. schimperi. The inferred ML cladogram shown (Figure 2) both Asia and African Termitomyces samples in our analysis demonstrated a well-supported monophyletic group with bootstrap value of $99 \%$. This result was corresponding with the previous phylogenetic studies on this genus (Aanen et al., 2002; RoulandLefevre et al., 2002; Froslev et al., 2003). Moreover, the monophyletic tree from pure Ethiopian Termitomyces collection and a combination of African and Asian Termitomyces samples may suggest their common origin.

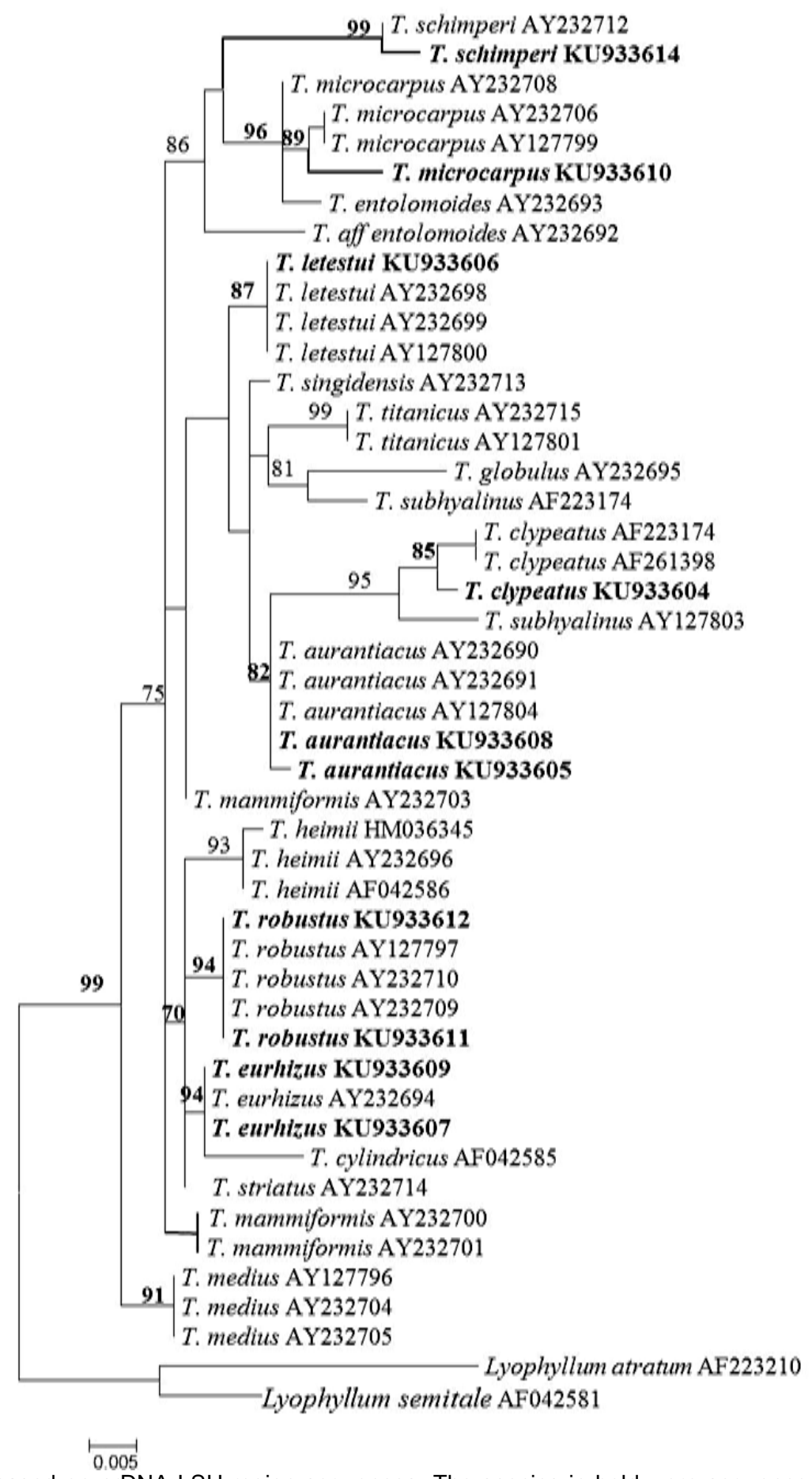

Figure 2: ML tree based on nrDNA LSU region sequences. The species in bold were sequenced by the authors. The percentage of trees in which the associated taxa clustered together is shown above the branches. Evolutionary analyses were conducted in MEGA6 
Rediet Sitotaw et al.,

Results of LSU sequence alignment showed that the two sequences of $T$. eurhizus (KU933607, KU933609) which were collected from different environments (Table 2) have identical sequences and similar results were observed with $T$. robustus (KU933611, KU933612). Termitomyces microcarpus (KU933610) and T. clypeatus (KU933604) collected from Menge have low LSU sequence similarity with both African and/or Asian collections, however they form a sister group with bootstrap support value of 89 and 85 respectively for the clade.
Sci. Technol. Arts Res. J., Oct-Dec 2015, 4(4): 49-57

Except $T$. robustus and $T$. schimperi the rest 5 species of Termitomyces were also commonly found in the other region of Ethiopia as reported by Teferi et al., (2013). During the present study it was documented that all Termitomyces species are in use for culinary purposes during the rainy season by the native community but only few of them (T. microcarpus and $T$. clypeatus) are known for medicinal utility for treatment of indigestion and malnutrition.

Table 2: Termitomyces specimen examined from Menge District

\begin{tabular}{|c|c|c|c|c|c|c|}
\hline Voucher & Taxa & Habitat & Geographical coordinates & $\begin{array}{l}\text { Altitude } \\
\text { (m.a.s.I) }\end{array}$ & Use & $\begin{array}{c}\text { Vernacular } \\
\text { Name }\end{array}$ \\
\hline HMAS273464 & T. aurantiacus & FA & $10^{\circ} 19^{\prime} 51^{\prime \prime} \mathrm{E} \quad 34^{\circ} 42^{\prime} 33^{\prime \prime} \mathrm{N}$ & $1238 \mathrm{~m}$ & $E$ & Abenega \\
\hline HMAS273466 & T. aurantiacus & GR & $10^{\circ} 19^{\prime} 48^{\prime \prime} \mathrm{E} \quad 34^{\circ} 42^{\prime} 32^{\prime \prime} \mathrm{N}$ & $1174 m$ & $E$ & Abenega \\
\hline HMAS273462 & T. clypeatus & FA & $10^{\circ} 18^{\prime} 50^{\prime \prime} \mathrm{E} \quad 34^{\circ} 42^{\prime} 33^{\prime \prime} \mathrm{N}$ & $1238 m$ & $E \& M$ & Akukufi \\
\hline HMAS273458 & T. eurrhizus & GR & $10^{\circ} 19^{\prime} 48^{\prime \prime} \mathrm{E} \quad 34^{\circ} 42^{\prime} 31^{\prime \prime} \mathrm{N}$ & $1174 m$ & $E$ & Tsergunu \\
\hline HMAS273459 & T. eurrhizus & FA & $10^{\circ} 20^{\prime} 411^{\prime \prime} \mathrm{E} \quad 34^{\circ} 48^{\prime}, 04^{\prime \prime} \mathrm{N}$ & $1174 m$ & $E$ & Tsergunu \\
\hline HMAS273763 & T. letestui & FA & $10^{\circ} 20^{\prime} 41^{\prime \prime} \mathrm{E} \quad 34^{\circ} 48^{\prime} 04^{\prime \prime} \mathrm{N}$ & $1174 m$ & $E$ & Afifi \\
\hline HMAS273461 & T. microcarpus & FA & $10^{\circ} 17^{\prime} 50^{\prime \prime} \mathrm{E} 34^{\circ} 44^{\prime} 00^{\prime \prime} \mathrm{N}$ & $1174 m$ & $E \& M$ & Aburalu \\
\hline HMAS273465 & T. robustus & FA & $10^{\circ} 19^{\prime} 47^{\prime \prime} \mathrm{E} \quad 34^{\circ} 51^{\prime} 10^{\prime \prime} \mathrm{N}$ & $1135 \mathrm{~m}$ & $E$ & Gultse \\
\hline HMAS273456 & T. robustus & GR & $10^{\circ} 20^{\prime} 10^{\prime \prime} \mathrm{E} 34^{\circ} 44^{\prime} 35^{\prime \prime} \mathrm{N}$ & $1278 m$ & $E$ & Gultse \\
\hline HMAS273460 & T. schimperi & $\mathrm{FO}$ & $10^{\circ} 14^{\prime} 05^{\prime} \mathrm{E} \quad 34^{\circ} 48^{\prime} 18^{\prime \prime} \mathrm{N}$ & $1332 m$ & $E$ & Zoma \\
\hline
\end{tabular}

$\mathrm{FO}=$ Forest, $\mathrm{FA}=$ Farm area, $\mathrm{GR}=$ grazing land; In Vernacular name, quoted names are in Arutana

(widely spoken language in the study area). $\mathrm{E}=\mathrm{Edible}, \mathrm{M}=\mathrm{Medicinal}$

Taxonomic Description of Termitomyces Collected from Menge District

Based on morphological characteristics, the habitat, geographic location and vernacular name all our collection provided in table 2 . All identified species are described in detail and illustrated.

Termitomyces aurantiacus (R. Heim) R. Heim in Termites et Champignons (Paris): 56 (1977). (Figure 3 $(\mathrm{A} 1-4))$

Pileus 6-10 cm in diam., conical- applanate, with a small and pointed perforatorium; surface bright reddish/ orange to brown and darker at the centre, glabrous. Margin radially striate and splitting, slightly viscid when moist. Lamellae free, 3-6 $\mathrm{mm}$ wide, white and crowded, with few lamellulae. Stipe 6-7 × $1.5-2.0 \mathrm{~cm}$, central; surface greyish white to brownish, smooth, solid; pseudorrhiza white, up to $15 \mathrm{~cm}$, cylindrical but tapering downward the base, sometimes slightly swollen before tapering. Context white, thick and firm. Basidiospores deposit pinkish cream. Taste mild. Odor mushroomy.

Basidiospores 5-7.5 $\times 3.5-4.5 \mu \mathrm{m}$, average length $(\mathrm{avl}) \times$ average width $(\mathrm{avw})=6.25 \times 4 \mu \mathrm{m}, \mathrm{Q}(\mathrm{avl} / \mathrm{avw})=$ $1.4-1.6$, avQ $=1.5$ ovoid to ellipsoid, thin-walled and subhyaline. Basidia 16-20 × 5-7.5 $\mu \mathrm{m}$, clavate, bearing four sterigmata, hyaline and thin-walled. Lamella margin heterogeneous. Cheilocystidia 22-40 × 10-25 $\mu \mathrm{m}$, clavate, thin-walled and hyaline. Hymenophoral trama subregular, thin-walled and hyaline hyphae, 4-15 $\mu \mathrm{m}$ diam. Clamp connection absent.

Remark: According to He (1985), T. aurantiacus can easily be distinguished from other species of the genus by its cylindrical pseudorrhiza and bright reddish to orange pileus and its firm texture (Pegler and Vanhaecke 1994) which is in line with our observation. However in this study authors didn't observe small squamules cited by $\mathrm{He}$ (1985) on the surface of the stipe. This may be due to the nature of the ephemeral remains of partial veil that can not be observed in mature material of $T$. aurantiacus. It is a well- known edible species sometimes appear in the local market during mid of the rainy season.

Termitomyces clypeatus R. Heim, Bull. Jard. bot. État Brux. 21: 207 (1951) (Figure 3. (B1- 4))

Pileus 4-6 cm in diam., conical becoming applanate with strongly spiniform to acutely pointed umbo and irregularly lobed margin; umbo at first brownish fading to ash-brown, lighter towards the margin, smooth, fibrillose, silky and viscid when wet, otherwise dry; context of pileus white, thin. Lamellae white to pinkish, free, crowded. Stipe 5-11 × 0.5-1 cm, whitish, solid, central, cylindrical and with a slightly bulbous base, with tapering pseudorrhiza. Annulus absent. Basidiospores deposit pinkish cream. Taste mild, pleasant. Odour mild, weak.

Basidiospores 5.5-7.0 $\times 3.5-4.5 \mu \mathrm{m}$, avl $\mathrm{x}$ avw $=6.25$ x $4 \mu \mathrm{m}, \mathrm{Q}=1.57-1.55$, avQ=1.56, broadly ellipsoidal hyaline and smooth. Basidia 20-25 × 7-9 $\mu \mathrm{m}$, clavate, bearing four sterigmata. Lamella margin heteromorphous with crowded cheilocystidia and basidia. Cheilocystidia 18-25 × 8-18 $\mu \mathrm{m}$, pyriform, hyaline with a faintly thickened wall. Hymenophoral trama regular, hyaline. Clamp connection absent.

Remark: Termitomyces clypeatus is one of the smallest species of the genus. It partially resembles $T$. tylerianus in fruit body dimensions, but it differs in exhibiting a spiniform to acute umbo with a silky pileal surface and with greyish brown cap, whitish gills and long stipe with black pseudorrhiza (Pegler 1977). It is edible and used as medicine among the local people to treat 
Rediet Sitotaw et al.
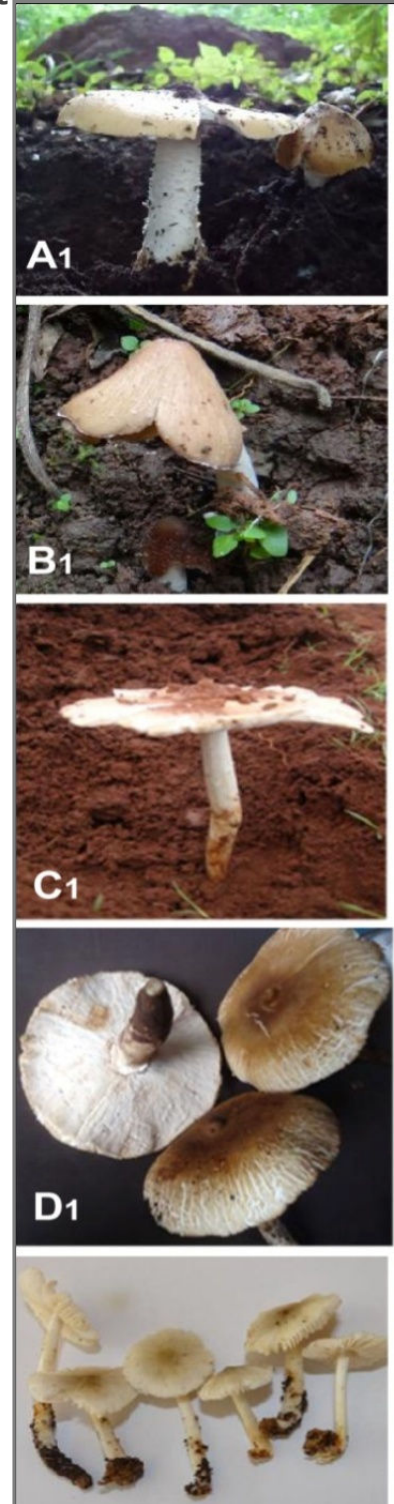

E1
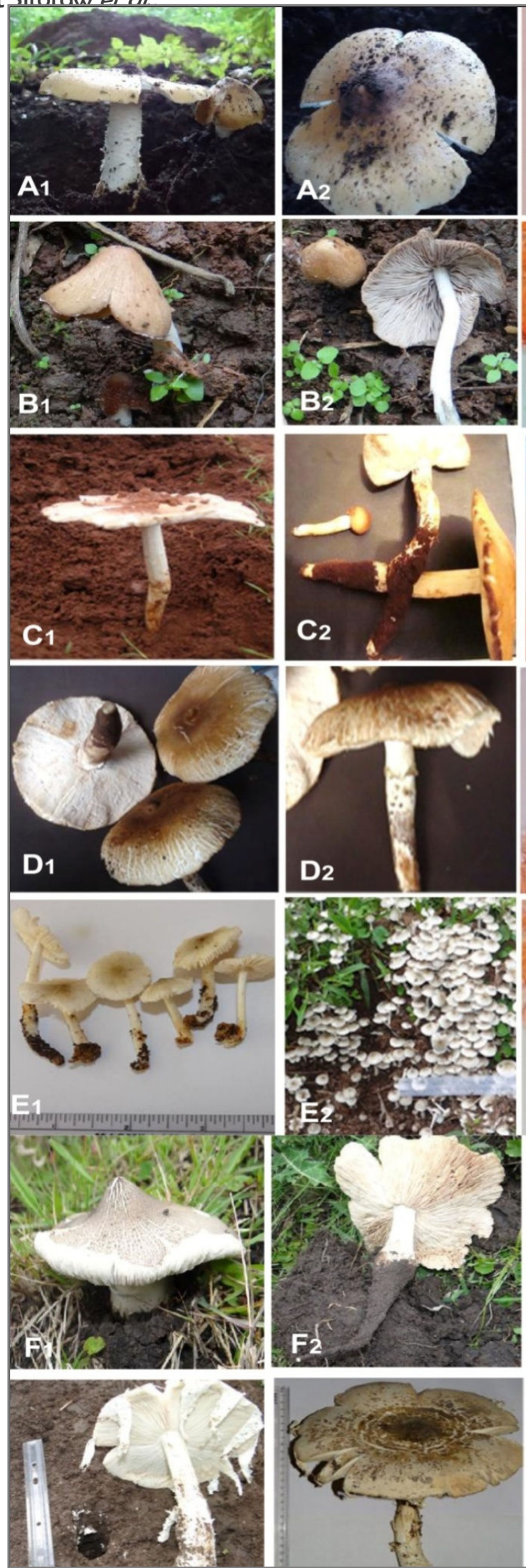

Sci. Technol. Arts Res. I. Oct-Dec 2015.4(4); 49-57
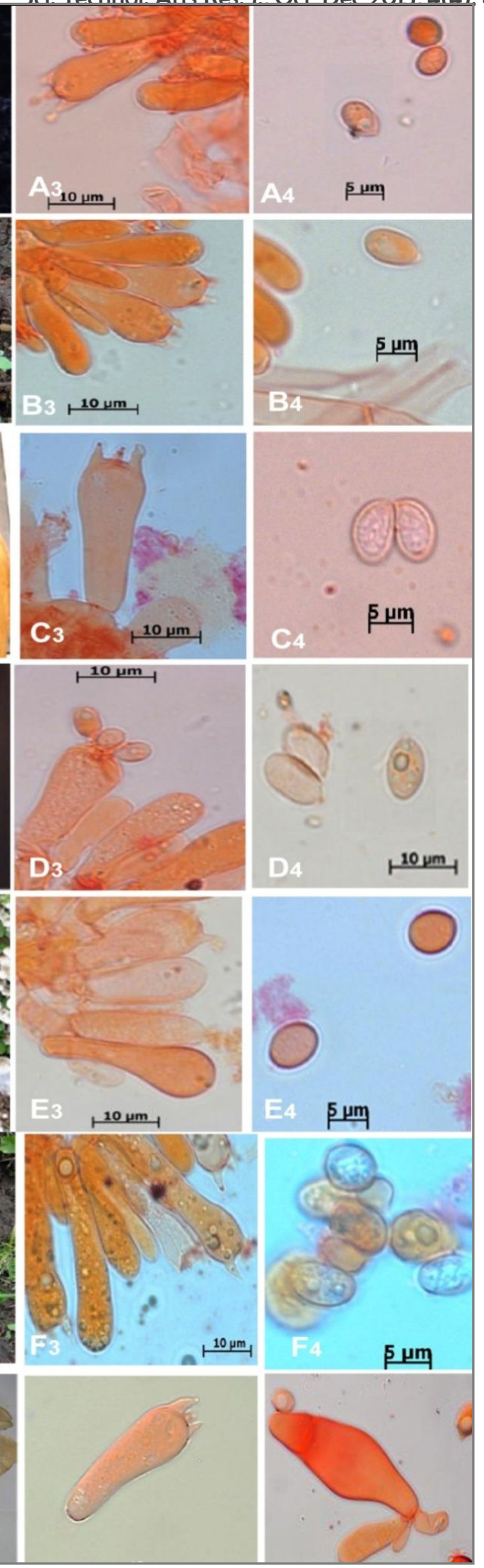

Figure 3: A1-A4: Termitomyces aurantiacus, B1-B4: T. clypeatus, C1-C4: T. eurrhizus, D1-D4: T. letestui, E1-E4: T. microcarpus, F1-F4: T. robustus, G1-G4: T. schimperi. 1\& 2 represent- Basidiomata, 3- Basidia and Cheilocystida, 4- Basidospores 
Rediet Sitotaw et alo,

problems related to gastric and constipation in adults and to treat underweight children. The health benefit of this species also indicated on reports from West Africa and Asia (Anderson et al., 2013; Adhikari et al., 2005; Boa, 2004; Okhuoya and Akpaja, 2005).

Termitomyces eurrhizus (Berk.) R. Heim [as 'eurhizus'], Arch. Mus. Hist. Nat. Paris, ser. 6 18: 140 (1942) (Figure 3. $(C 1-4))$.

Pileus $5-22 \mathrm{~cm}$ in diam., conico-campanulate then to nearly plane with a broadly ambonate prforatorium; surface greyish brown over the perforatorium becoming usually paler near the margin, silky striat towards the margin. Margin slightly incurved, splitting at maturity. Lamellae sub-free to adnexed, whitish cream to pinkish, 8-10 $\mathrm{mm}$ wide, moderately crowded with few lamellulae. Stipe 5-20 × 1-4 cm above ground, central, solid, cylindrical, surface whitish, attenuating as an elongate pseudorrhiza, up to $0.25 \mathrm{~m}$. Context fleshy, white, becoming thin towards the margin, thin-walled-hyphae, 3$5 \mu \mathrm{m}$ diam. Basidiospores deposit brownish pink. Taste and odor mild, pleasant.

Basidiospores 6.0-8.5 $\times$ 4.0-5.5 $\mu \mathrm{m}$, avl $\times$ avw $=7.5 \times$ $5.0 \mu \mathrm{m}, \mathrm{Q}=1.3-1.4$, avQ $=1.35$ ellipsoid, hyaline, inamyloid, smooth, thin-walled. Basidia 20-25 × 6-10 $\mu \mathrm{m}$, clavate, bearing four sterigmata. Lamella margin with crowded cheilocystidia. Cheilocystidia pyriform or rarely obovoid, 20-40 × 9-25 $\mu \mathrm{m}$, hyaline with a slightly thickened wall. Hymenophoral trama regular of hyphae of 3-5 $\mu \mathrm{m}$ in diam., hyaline. Clamp connection absent.

Remarks: The special character of $T$. eurrhizus is the thick pseudorrhiza, which is black below the ground level. The structure of this species has been dealt with considerable detail by Petch (1913) who accepted two distinct forms; with persistent annulus and with out annulus commenting that the two forms were identical in size, shape, structure of pileus and gills, size and colour of spores. No persistent annulus was clearly observed in all of our $T$. eurrhizus collections in this study. However it is quite clear that the two forms are simply represent the same species. As described in Pegler (1977) the presence or absence of a ring is a more or less an accidental phenomenon brought about by a difference in the point of dehiscence of the universal veil. T. eurrhizus is a common species at grassland, edges of forests and cultivated fields in the study area. It is esteemed as delicacy by the indigenous people but not common at the local market.

Termitomyces letestui (Pat.) R. Heim, Arch. Mus. Hist. Nat. Paris, ser. 6 18: 109 (1942). (Figure 3. (D1-4))

Pileus $12-20 \mathrm{~cm}$ in diam., convex, with mammillate perforatorium, surface cream to light brown becoming dark brown or rust brown towards the center, finely squamulose at the disk. Margin incurved, splitting radially. Lamellae free, up to $6 \mathrm{~mm}$ wide, cream to pinkish, thin, crowded with numerous lamellulae up to $12 \mathrm{~mm}$ broad. Stipe $8-15 \times 1-3.5 \mathrm{~cm}$, central, cylindrical, surface whitish, prolonged below in to tapering pseudorrhiza. Context white, firm, up to $25 \mathrm{~mm}$ thick. Annulus white to whitish, membranous, superior and pendant. Basidiospores deposit pinkish cream. Taste mild and Odor strong and pleasant.
Sci. Technol. Arts Res. J., Oct-Dec 2015, 4(4): 49-57

Basidiospores 5.5-8.5 × 4.0-5.5 $\mu \mathrm{m}$, avl $\times$ avw $=7 \times$ 4.7 $\mu \mathrm{m}, \mathrm{Q}=1.37-1.5$, avQ $=1.4$ obovoid to ellipsoid hyaline, thin-walled. Basidia 20-25 $\times 5-7 \mu \mathrm{m}$, clavate, bearing four sterigmata. Lamella margin heteromorphous with crowded cheilocystidia. Cheilocystidia 20-45 × 9-22 $\mu \mathrm{m}$, mostly broadly clavate but sometimes cylinderic, with a fairly thick wall, hyaline. Subhymenial layer fairly broad, 7- $10 \mu \mathrm{m}$ wide. Hymenophoral trama sub regular to vaguely bilateral, 2-6 $\mu \mathrm{m}$ diam., hyaline, with thin-walled hyphae. Clamp connection absent.

Remarks: It is recognized mainly by its large and fleshy pileus with a characteristic mammillate perforatorium and by the sheathing annulus. Termitomyces letestui is wide spread throughout Menge district and represent one of the largest species. It is one of the first mushrooms to appear at the beginning of the rainy season (mid of June). It is edible and highly prized due to its good test. It is offered for sale in local markets and on roadsides at quite an expensive price.

Termitomyces microcarpus (Berk. \& Broome) R. Heim, Arch. Mus. Hist. Nat. Paris, ser. 6 18: 128 (1942). (Figure 3. (E1-4))

Pileus $1-1.5(2.5) \mathrm{cm}$ in diam., campanulate to convex then expanding, broad convex to almost applanate, often umbonate, upper surface whitish to cream, darkening at the center, dry. Margin incurved or straight. Lamellae free, thin, white, 1-2 $\mathrm{mm}$ wide, moderately crowded with lamellulae. Stipe 2-4(-5) × $0.1-0.3 \mathrm{~cm}$, central, solid, cylindric, sometimes with small bulbose base, surface whitish, smooth, lacking pseudorrhiza. Context white, thin. Annulus absent. Basidiospores deposit light pinkish. Taste mild. Odor mild, sometimes odourless.

Basidiospores 6.0-8.5 $\times 3.5-4.5 \mu \mathrm{m}$, avl $\times$ avw $=7.5 \times$ $4.15 \mu \mathrm{m}, \mathrm{Q}=1.5-1.8$, avQ $=1.65$, ovoid to ellipsoid hyaline, with usually one refractive guttule, inamyloid, thinwalled. Basidia 20-25 × 7-9 $\mu \mathrm{m}$, clavate, bearing four sterigmata. Lamella margin fertile, sometimes with few cheilocystidia. Cheilocystidia and pleurocystidia similar, inconstant and often rare on the lamella edge, 15-40 × 9$16 \mu \mathrm{m}$, pyriform to cylindric, slightly thickened wall. Hymenophoral trama regular, hyaline hyphae. Hyphae of pileipellis 3-4 $\mu \mathrm{m}$ in diam., radially paralled hyphae. Clamp connection absent.

Remarks: Distinctive characteristics of this Termitomyces species is its small size, occurrence in dense troops and the absence of pseudorrhiza, however its association with termite, the presence of pinkish spore and other micromorphological characters that it shares with other species in the genus lead mycologists to put it under this genus. In contrast to previous researches (Pegler, 1977; Pegler and Vanhaecke 1994), T. microcarpus from Menge has cream colour spore deposit instead of the pink spore deposit. It is common and abundance around farming field and semi-opening bamboo forest in Menge District from end of June to August. It is edible and well-liked for its test and flavour and medicinal benefit, however due to its small size elder people do not prefer it since it takes much time to collect even for one meal.

Termitomyces robustus (Beeli) R. Heim, Bull. Jard. bot. État Brux. 21: 210 (1951). (Figure 3. (F1-4)) 
Rediet Sitotaw et alo,

Pileus 7-11 cm diameter, at first conical then expanding to convex, pointed to perforatorium, surface grey with scrobiculate. Lamellae free, crowded 5-6 mm wide, ivory. Stipe 6-8 × 3-7 cm thick, white, solid, central, cylindrical slightly tapering downward. Context white, firm, up to $12 \mathrm{~mm}$ thick. Annulus absent in mature specimens. Basidiospores deposit pinkish-cream. Taste and Odor mild.

Basidiospore 4-8×3-4.5 $\mu \mathrm{m}$, avl $\times$ avw $=6 \times 3.7 \mu \mathrm{m}, \mathrm{Q}$ $=1.3-1.7$, avQ $=1.5$ ovoid to ellipsoid, thin-walled, inamyloid, hyaline. Basidia 18-25 × $6-8 \mu \mathrm{m}$, clavate, bearing four sterigmata. Lamella margin heteromorphous thin-walled, subhyaline. Cheilocystidia 25-40 × 10-20 $\mu \mathrm{m}$, clavate, with a fairly thick wall, hyaline. Hymenophoral trama vaguely bilateral, 3-6 $\mu \mathrm{m}$ diam., hyaline, with thinwalled hyphae. Clamp connection absent

Remarks: Termitomyces robustus is readily recognized by its large, tough basidiomata with brown cap surface conical umbo and a swollen stipe and blackish psudorrhiza. The fruiting body appear after good rains from mid-July until end of September. It is edible and tasty.

Termitomyces schimperi (Pat.) R. Heim, Arch. Mus. Hist. Nat. Paris, ser. 6 18: 114 (1942) (Figure 3. (G1-4))

Pileus $18-40 \mathrm{~cm}$ in diam., convex to flat, lacking umbo, covered with thick large persistent scales concentric and forming plate-like covering at disc, surface white but stained light brown to reddish-brown by the soil of the mound. Margin entire, splitting radially, with persistent, long and membranous partial veil. Lamellae free to adnexed, up to $10 \mathrm{~mm}$ wide, whitish to cream, moderately crowded. Stipe $30-40 \times 3-4 \mathrm{~cm}$, cylindric, swollen towards the base then tapering to a long pseudorrhiza. context thick, white. Annulus absent. Basidiospores deposit cream with pinkish touch. Taste mild. Odor pleasant.

Basidiospore 5-9 $\times 4-5.5 \mu \mathrm{m}$, avl $\times$ avw $=7 \times 4.7 \mu \mathrm{m}$, $\mathrm{Q}=1.25-1.6$, avQ $=1.4$ ovoid to ellipsoid, thick-walled, inamyloid, hyaline. Basidia 18-30 × 5-8.5 $\mu \mathrm{m}$, clavate, bearing four sterigmata. Lamella margin heteromorphous. Cheilocystidia 35-55 × 15-20 $\mu \mathrm{m}$, clavate, with thick wall, hyaline. Hymenophoral trama bilateral, 4-6 $\mu \mathrm{m}$ diam., hyaline, with thick-walled hyphae. Clamp connection absent.

Remark: Termitomyces schimperi is well known for its large robust fruiting body, usually the cap may reach about $40 \mathrm{~cm}$. in diam (Pegler, 1977; Pegler and Piearce, 1980; Singer, 1986). It is easily recognized by its rough scaly cap and stem, the brown scales of the cup usually in the form of radiating concentric rings unlike many other Termitomyces species it lacks an umbo. Usually found on top of termite hills. It usually appear after heavy rains from July to mid September which is the main rainy season in the study area.

\section{CONCLUSION}

Termitomyces is a paleotropical genus and many more new taxa of Termitomyces are likely to be reported from this part of the world. Being in tropics, there is a high possibility of finding new Termitomyces species to the world and new records to the country this underscores the need for further study of the genus. As this is the first

\section{Sci. Technol. Arts Res. J., Oct-Dec 2015, 4(4): 49-57}

report on morphological and molecular taxonomy of this genus, we hope that many more reports on Termitomyces species will follow. This study also confirmed that phylogenetic analysis of LSU rDNA sequences useful approach which helps to identify Termitomyces species in a combination with morphological classification.

\section{Acknowledgements}

The authors would like to acknowledge the financial support of Addis Ababa University, Wollega University and Organization for Women in Science for Developing World (OWSD). Rediet Sitotaw Kebede is a recipient of the OWSD postgraduate fellowship to study in Yi-Jian Yao's laboratory for her PhD degree at the Institute of Microbiology, Chinese Academy of Sciences.

\section{Conflict of Interest}

None Declared.

\section{REFERENCES}

Aanen, D.K., Eggleton, P., Rouland-Lefèvre, C., Frøslev, T.G., Rosendah, S. and Boomsma, J.J. (2002). The evolution of fungus-growing termites and their mutualistic fungal symbionts. Proceedings of the National Academy of Sciences of the United States of America 99: 1488714892.

Adhikari, M.K., Devkota, S. and Tiwari, R.D. (2005). Ethnomycolgical Knowledge on Uses of Wild Mushrooms in Western and Central Nepal. Our Nature 3:13-19.

Alasoadura, S.O. (1966). Studies in the higher fungi of Nigeria, Macrofungi associated with termites. Nova Hedwigia 11: 387-383.

Anderson, M.K., Lake, F.K. and Lake, F.K. (2013). California Indian Ethnomycology and Associated Forest Management. Journal of Ethnobiology 33(1): 33-85.

Boa, E. (2004). Wild edible fungi. A global overview of their use and importance to people. Non-wood Forest Product 17. Rome: Food and Agriculture Organization of the United Nations.

BRFSS. (2004). Benishangul-gumuz region Food Security Strategy, Annual Report. Asossa. pp 9-30.

Friis, I.B. and Sebsebe, D. (2001). Vegetation maps of Ethiopia and Eritrea. A review of existing maps and the need for a new map for the flora of Ethiopia and Eritrea. 399-439, in: Biodiversity Research in the Horn of Africa Region. Proceedings of the $3^{\text {rd }}$ International symposium on the Flora of Ethiopia and Eritrea at the Carlsberg Academy, Copenhagen.

Frøslev, T.G., Aanen, D.K., Læssøe, T. and Rosendahl, S. (2003). Phylogenetic relationships of Termitomyces and related taxa. Mycological Research 107: 1277-1286.

Gómes, L.D. (1995). Una nueva specie neotropical de Termitomyces (Agricales: Termitomycetaceae). Revista de Biologia Tropical 42: 439-451.

Hall, T.A. (1999). BioEdit: a user-friendly biological sequence alignment editor and analysis program for Windows 95/98/NT. Nucleic Acids Symposium Series 41: 95-98.

He, S.C. (1985). Taxonomic studies of Termitomyces from Guizhou Province of China. Acta Mycologica Sinica 4: 103-108.

Heim, R. (1942). Nouvelles études descriptives sur les agarics termitophiles d'Afrique tropicale. Arch. Mus. Natl. Hist. Nat. sér. 6(18): 1-60. 
Rediet Sitotaw et alo,

Heim, R. (1952). Les Termitomyces du Cameroun et du Congo français. Denkschr. Schweiz. Naturf. Ges. 80: 129.

Heim, R. (1977). Termites et Champignons. Paris: Société Nouvelle Des Éditions Boubée. pp 1-206.

Kirk, P.M., Cannon, P.F., Minter, D.W. and Stalpers. J.A. (2008). Dictionary of the Fungi, $10^{\text {th }}$ ed. The Centre for Agriculture and Bioscience International (CABI). Wallingford, UK.

Kimura, M. (1980). A simple method for estimating evolutionary rate of base substitutions through comparative studies of nucleotide sequences. Journal of Molecular Evolution 16: 111-120.

Moncalvo, J.M., Lutzoni, F.M., Rehner, S.A., Johnson, J. and Vilgalys, R. (2000). Phylogenetic relationships of agaric fungi based on nuclear large subunit ribosomal DNA sequences. Systematic Biology 49: 278-305.

Morris, B. (1986). Notes on the genus Termitomyces Heim in Malawi. Society of Malawi Journal 39: 40-49.

Mossebo, D.C., Amougou, A. and Atangana, R.E. (2002). Contribution a l'étude du genre Termitomyces (Basidiomycètes) au Cameroon: écologie et systematique. Bulletin de la Société Mycologique de France 118: 195-249.

Okhuoya, J. A. and Akpaja, E. O. (2005). Mycomedicine and Ethnomycology: The Nigerian Experience. International Journal of Medicinal Mushrooms 7: 439-440.

Otieno, N.C. (1964). Contributions to knowledge of Termite fungi in East Africa. Proceedings of the East African Academy 11: 108-120.

Pegler, D.N. (1977). A preliminary agaric flora of East Africa. Kew Bulletin 6: 1-615.

Pegler, D.N. and Rayner, R.W. (1969). A contribution to the Agaric flora of Kenya. Kew Bulletin 23:347-412.

Pegler, D.N. and Vanhaecke, M. (1994). Termitomyces of Southeast Asia. Kew Bulletin 49: 717-736.

Petch, T. (1913). Termite fungi: a résumé. Annals of the Royal Botanic Garden (Peradeniya) 5: 303-341.

Rouland-Lefevre, C., Diouf, M.N., Brauman, A. and Neyra M. (2002). Phylogenetic relationships in Termitomyces (family Agaricaceae) based on the nucleotide sequence of ITS: A first approach to elucidate the evolutionary
Sci. Technol. Arts Res. J., Oct-Dec 2015, 4(4): 49-57

history of the symbiosis between fungus-growing termites and their fungi. Molecular Phylogenetic Evolution 22: 423429.

Singer, R. (1986). The Agaricales in modern taxonomy. Koeltz Scientific Books $4^{\text {th }}$ ed, Koenigsternm, Germany, pp 20-99.

Sitotaw R., Li, Y., Wei, T.-Z., Abate, D. and Yao, Y-J. (2015). Two new records of Agaricus spp. from Ethiopia. Mycotaxon 133: 1171-1183.

Teferi, Y., Muleta, D. and Woyessa, D. (2013). Mushroom consumption habits of Wacha Kebele residents , southwestern Ethiopia, Global Research Journal of Agricultural and Biological Sciences 6: 6-16.

Thompson, J.D., Higgins, D.G. and Gibson, T.J. (1994). CLUSTAL W: Improving the sensitivity of progressive multiple sequence alignment through sequence weighting, position, specific gap penalties and weight matrix choice. Nucleic Acids Research 22: 4673-4680.

Tang, B.H., Wei, T.Z. and Yao Y.J. (2006) [as 2005]. Type revision of three Termitomyces species from India. Mycotaxon 94: 93-102.

Tamura, K., Stecher, G., Peterson, D., Filipski. A., and Kumar S. (2013). MEGA6: Molecular Evolutionary Genetics Analysis version 6.0. Molecular Biology and Evolution 30: 2725-2729.

Tuno, N. (2001). Mushroom utilization by the Majangir, an Ethiopian tribe. The Mycologist 15: 78-79.

Van der Westhuizen, G.C.A. and Eicker, A. (1990). Species of Termitomyces occurring in South Africa. Mycological Research 94: 923-937.

Wei, T.Z., Yao, Y.J., Wang, B. and Pegler, D.N. (2004). Termitomyces bulborhizus sp. nov. from China, with a key to allied species. Mycological Research 108: 1458-1462.

Wei, T.Z., Yao. Y.J., and T.H, L.I. (2003). First records of Termitomyces entolomodes in China. Mycotaxon 88: 433438.

Yao, Y.J. and Pegler, D.N. (1999). Application of ITS (nrDNA) sequences in the phylogenetic study of Tyromyces s.l. Mycological Research 103: 219-229.

Zhang, Z.F. and Ruan, X.Y. (1986). A new species of Termitomyces-Termitomyces macrocarpus Zhang et Ruan sp. nov. Acta Mycologica Sinica 5: 10-13. (in Chinese). 